\title{
Proteolytic cleavage of the extracellular domain affects signaling of parathyroid hormone receptor 1
}

\section{Christoph Klenk ${ }^{1, \#^{*}}$, Leif Hommers ${ }^{2,3,4}$, Martin J. Lohse $\mathrm{H}^{1,5,6,7}$}

2 Institute of Pharmacology and Toxicology, University of Würzburg, Würzburg, Germany

3 Interdisciplinary Center for Clinical Research, University Hospital of Würzburg, Würzburg,

4 Germany

$5{ }^{3}$ Department of Psychiatry, Psychosomatics and Psychotherapy, Center for Mental Health,

6 University Hospital of Würzburg, Würzburg, Germany.

$7{ }^{4}$ Comprehensive Heart Failure Center (CHFC), University Hospital of Würzburg, Würzburg,

8 Germany.

$9 \quad{ }^{5}$ Rudolf Virchow Center, University of Würzburg, Würzburg, Germany

$10 \quad{ }^{6}$ Max Delbrück Center for Molecular Medicine (MDC), Berlin, Germany

$11{ }^{7}$ ISAR Bioscience Institute, Planegg, Germany

12 \#present address: Department of Biochemistry, University of Zurich, Zurich, Switzerland 13

14 *Corresponding author: Christoph Klenk, c.klenk@bioc.uzh.ch 


\section{Abstract}

Parathyroid hormone 1 receptor (PTH1R) is a member of the class B family of G proteincoupled receptors, which are characterized by a large extracellular domain required for ligand binding. We have previously shown that the extracellular domain of PTH1R is subject to metalloproteinase cleavage in vivo that is regulated by ligand-induced receptor trafficking and leads to impaired stability of PTH1R. In this work, we localize the cleavage site in the first loop of the extracellular domain using amino-terminal protein sequencing of purified receptor and by mutagenesis studies. We further show, that a receptor mutant not susceptible to proteolytic cleavage exhibits reduced signaling to $G_{s}$ and increased activation of $G_{q}$ compared to wild-type PTH1R. These findings indicate that the extracellular domain modulates PTH1R signaling specificity, and that its cleavage affects receptor signaling.

\section{Introduction}

Parathyroid hormone 1 receptor (PTH1R) is a key regulator of blood calcium levels and bone metabolism in response to parathyroid hormone (PTH). Moreover, activation of PTH1R by parathyroid-related hormone peptide (PTHrP) has been implicated in fetal development and in malignancy-associated hypercalcemia (1). PTH1R is a member of the class B family of G protein-coupled receptors (GPCRs) which are characterized by a large N-terminal extracellular domain (ECD; 100 to 180 residues) that is critically involved in ligand binding $(2,3)$. Similar to other class B GPCRs, the ECD of PTH1R consists of two pairs of antiparallel $\beta$-strands flanked by a long and a short $\alpha$-helical segment at the $\mathrm{N}$ - and C-terminal end, respectively. The overall conformation is constrained by three conserved disulfide bonds which are required for proper folding and for ligand binding (4-7). The ECD is oriented in an upright position above the membrane surface with residues 15-34 of PTH binding into a groove formed by the ECD and the N-terminal part of the ligand protrudes as a continuous $\alpha$ helix into the transmembrane domain of PTH1R (Fig. 1) (7). In line with the receptor structure, a two-step activation model has been proposed, where first the C-terminal part of PTH binds to the extracellular domain, and then the N-terminal part of PTH interacts with the receptor core, thereby leading to receptor activation $(8,9)$. PTH1R couples to multiple heterotrimeric $\mathrm{G}$ protein subtypes and can activate several signaling pathways concomitantly. Predominantly, adenylyl cyclases are stimulated by activation of $\mathrm{G}_{\mathrm{s}}$ as well as phospholipase $\mathrm{C} \beta$ by $\mathrm{G}_{\mathrm{q}}$ (10-12). Moreover, activation of $\mathrm{G}_{\mathrm{i} / \mathrm{o}}$ resulting in inhibition of adenylyl cyclase and activation of $\mathrm{G}_{12 / 13}$ leading to phospholipase $\mathrm{D}$ and RhoA activation, as well as activation of mitogen-activated protein kinases through G protein-dependent and -independent mechanisms 
have been reported (13-18). PTH1R activation can have anabolic and catabolic effects on bone. While continuous administration of PTH enhances osteoclastogenesis leading to bone resorption and calcium liberation, intermittent administration of PTH results in bone formation through enhancing osteoblast differentiation and survival, which is used as a treatment option for severe osteoporosis $(19,20)$. Although the exact molecular mechanisms are not clear yet, differential activation of signaling pathways seems to play an important role in these opposing effects upon PTH1R activation. While $\mathrm{G}_{\mathrm{s}}$-signaling is the predominant pathway for promoting PTH-induced bone formation, $\mathrm{G}_{\mathrm{q}}$-activation seems to have little or no effect on osteogenesis (21-23). In addition, $\beta$-arrestin recruitment was shown to be essential for selectively promoting bone formation upon treatment of mice with recombinant PTH(1-34) (24). Moreover, many of these effects appear to be regulated in a tissue- and celltype specific manner (25).

We have previously shown that the ECD of PTH1R can undergo proteolytic cleavage by an extracellular metalloproteinase resulting in reduced stability and degradation of the receptor.

We also demonstrated that N-terminal ECD cleavage occurred only at the cell surface, and that internalization of the receptor resulting from continuous activation by agonists prevented cleavage and thereby stabilized the receptor. Furthermore, our experiments suggested that the cleavage site is located within the first 90 residues of the receptor, however the exact position was not fully resolved (26). In the present study, we have localized the cleavage site in the unstructured loop of exon E2 within the PTH1R ECD. Moreover, we demonstrate that ECD cleavage results in an altered ligand efficacy of PTH changing the G protein-coupling of PTH1R from $G_{q}$ to $G_{s}$.

\section{Materials and Methods}

\section{Materials}

Lipofectamine 2000 was purchased from Thermo Fisher Scientific. $\left[\mathrm{Nle}^{8,18}, \mathrm{Tyr}^{34}\right] \mathrm{PTH}(1-34)$, a chemically more stable variant of native PTH, was purchased from Bachem and is referred to as PTH(1-34). Generation of a polyclonal rabbit anti-PTH1R (1781) antiserum was described previously (27). Anti-rabbit peroxidase-conjugated secondary antibodies were obtained from Dianova. Cy2-conjugated anti-rabbit antibody was from Jackson Immuno Research Lab. All cell culture media were obtained from PAN Biotech. All other reagents were of analytical grade from Sigma-Aldrich or Applichem. 


\section{cDNA constructs}

A Strep-Tag II (WSHPQFEK) was fused to the C-terminal end of human PTH1R (26) by PCR. Alanine mutations were introduced into the extracellular domain of PTH1R by overlap extension PCR. In total, 6 constructs with alanine blocks from $\mathrm{Leu}^{56}-\mathrm{Met}^{63}$, $\mathrm{Glu}^{64}-\mathrm{Ser}^{71}$, $\mathrm{Ala}^{72}-\mathrm{Arg}^{79}, \mathrm{Lys}^{80}-\mathrm{Leu}^{87}, \mathrm{Tyr}^{88}-\mathrm{Lys}^{95}$, and $\mathrm{Glu}^{96}-\mathrm{Tyr}^{103}$ were generated. All constructs were subcloned into pcDNA5/FRT vector (Thermo Fisher Scientific) using the restriction sites EcoRI and ApaI and verified by sequencing.

\section{Cell culture and transfection}

Flp-In CHO cells (Thermo Fisher Scientific) were maintained in 1:1 Dulbecco's modified Eagle's medium/ Ham's F12 medium containing $10 \%$ (v/v) fetal calf serum, $100 \mathrm{U} / \mathrm{ml}$ penicillin, $100 \mu \mathrm{g} / \mathrm{ml}$ streptomycin and $100 \mu \mathrm{g} / \mathrm{ml}$ Zeocin (Thermo Fisher Scientific). Cells were maintained at $37{ }^{\circ} \mathrm{C}$ in a humidified atmosphere of $5 \% \mathrm{CO}_{2}, 95 \%$ air. To generate stable cell lines, cells were transfected with pcDNA5/FRT-PTH1R plasmids using Lipofectamine 2000 according to the manufacturer's instructions. $48 \mathrm{~h}$ after transfection, cells were selected in culture medium where Zeocin was replaced by $600 \mu \mathrm{g} / \mathrm{ml}$ hygromycin B for approximately two weeks. Clonal cell lines were derived from limited dilution series and screened for expression of PTH1R by Western blot and immunocytochemistry.

\section{SDS-PAGE and Western blotting}

Cells were lysed in SDS-loading buffer [50 mM Tris (pH 6.8), 2\% (v/v) SDS, 10\% glycerol, 5 $\mathrm{mg} / \mathrm{ml}$ bromophenol blue] for $20 \mathrm{~min}$ on ice, briefly sonified and incubated at $45{ }^{\circ} \mathrm{C}$ for 20 min. For reducing conditions, 4\% (v/v) $\beta$-mercaptoethanol was added to the lysis buffer. Lysates were cleared by centrifugation and run on 10\% SDS-polyacrylamide gels in a MiniPROTEAN 3 cell apparatus (Biorad). Proteins were electroblotted onto Immobilon P membranes (Millipore) using a Bio-Rad Mini trans-blot cell apparatus at $100 \mathrm{~V}$ for $60 \mathrm{~min}$ at $4{ }^{\circ} \mathrm{C}$. The blots were probed with anti-PTH1R antibodies $(1: 4,000)$, followed by horseradish peroxidase-conjugated goat anti-rabbit $(1: 10,000)$ and detection on Super RX X-ray film (Fujifilm) using ECL Plus reagent (GE Healthcare).

\section{Purification of PTH1R}

Membranes from Flp-In CHO cells stably expressing PTH1R-Strep2 were prepared as described before (28). Membranes were solubilized in solubilization buffer [50 mM Tris- $\mathrm{HCl}$ (pH 7.4), $140 \mathrm{mM} \mathrm{NaCl}, 0.5 \%$ (w/v) n-dodecyl $\beta$-D-maltoside, $10 \mu \mathrm{g} / \mathrm{ml}$ soybean trypsin inhibitor, $30 \mu \mathrm{g} / \mathrm{ml}$ benzamidine, $5 \mu \mathrm{g} / \mathrm{ml}$ leupeptin, $100 \mu \mathrm{M}$ PMSF] for $2 \mathrm{~h}$, and insoluble material was removed by centrifugation for $1 \mathrm{~h}$ at $100,000 \times \mathrm{g}$. Solubilized PTH1R-Strep2 
114 was incubated with $1 \mathrm{ml}$ Strep-Tactin sepharose (IBA $\mathrm{GmbH}$ ) for $12 \mathrm{~h}$ under constant agitation and washed with 10 column volumes of wash buffer [100 mM Tris-HCl (pH 8.0), $1 \mathrm{mM}$ EDTA, $150 \mathrm{mM} \mathrm{NaCl}, 0.1 \%(\mathrm{w} / \mathrm{v})$ n-dodecyl $\beta$-D-maltoside]. Bound receptor was eluted with 1-2 column volumes of the same buffer supplemented with $2.5 \mathrm{mM}$ desthiobiotin and concentrated with a Microcon centrifugal filter device (10,000 MWCO, Millipore).

\section{Amino-terminal sequencing of cleaved receptor fragments}

120 Fifty $\mu \mathrm{g}$ of purified receptor fragments were blotted onto PVDF membranes and stained with

121 Coomassie Blue. The fragments were excised and subjected to automated Edman degradation

122 (Wita $\mathrm{GmbH}$ ).

\section{Immunocytochemistry and confocal imaging}

124 CHO cells stably expressing PTHR variants were grown on coverslips overnight. Cells were then exposed (or not) to $100 \mathrm{nM} \mathrm{PTH(1-34)} \mathrm{for} 30 \mathrm{~min}$ as indicated. Cells were fixed with 4\% paraformaldehyde and $0.2 \%$ picric acid in $0.1 \mathrm{M}$ phosphate buffer ( $\mathrm{pH} \mathrm{6.9)}$ ) for $30 \mathrm{~min}$ at room temperature and washed five times in PBS. For permeabilization cells were incubated for $5 \mathrm{~min}$ in methanol. After $10 \mathrm{~min}$ of preincubation in PBS containing $0.35 \%(\mathrm{w} / \mathrm{v}) \mathrm{BSA}$, cells were incubated with anti-PTH1R antibody at a dilution of 1:2,000 in PBS containing $0.35 \%(\mathrm{w} / \mathrm{v}) \mathrm{BSA}$ for $1 \mathrm{~h}$ at $37^{\circ} \mathrm{C}$. Bound primary antibody was detected with Cy2-labeled goat anti-rabbit IgG (1:400). Specimens were examined using a Leica SP2 laser scanning confocal microscope.

\section{Functional receptor assays}

134 Signaling assays were measured in Flp-In CHO cells stably expressing the indicated PTH1R variants. cAMP was measured using a RIA kit (Beckman Coulter), and inositol phosphates were separated by chromatographic separation of myo- $\left[2-{ }^{3} \mathrm{H}\right]$ inositol phosphates as described previously (29). Pharmacological data were analyzed in Prism v6.0 (GraphPad Software). A three-parameter logistic equation was fit to the data to obtain concentration-response curves and $\mathrm{E}_{\max }$ values. Statistical differences were analyzed using unpaired t-tests.

\section{Results}

141 Our previous findings suggested that the protease cleavage site is most likely located between

$142 \mathrm{Cys}^{48}$ and $\mathrm{Cys}^{108}$ (26), a region including exon E2 of PTH1R which is unique among all other 143 class B GPCRs and which forms a disordered loop in the crystal structures of the isolated 144 PTH1R ECD (4) and full length PTH1R (7) (Fig. 1). We therefore created a series of mutants 145 where stretches of 8 residues in this region were mutated to Ala to delineate the protease 
146 cleavage site (Fig. 2A). Each of the six resulting PTH1R variants was stably expressed in

147 Flp-In CHO cells, and expression and membrane targeting of the receptor were analyzed by 148 immunofluorescence (Fig. 2B) using an antibody detecting the C-terminal part of PTH1R 149 (26,27). All mutants exhibited a distinct membrane staining which was comparable to that of 150 wild-type receptor. Upon stimulation with $100 \mathrm{nM} \mathrm{PTH(1-34)} \mathrm{for} 30 \mathrm{~min}$, a sequestration of 151 receptor from the cell surface into endocytic vesicles was observed suggesting that each 152 receptor variant activated intracellular signaling pathways leading to receptor internalization.

153 To test whether any of the mutations had an effect on protease cleavage, the migration 154 patterns of PTH1R variants were analyzed by reducing SDS-PAGE and Western blotting. As 155 demonstrated previously, the ECD of PTH1R residing at the cell surface is cleaved by extracellular metalloproteinases. The resulting N-terminal fragment of the ECD $(\sim 10 \mathrm{kDa})$ remains tethered to the receptor core by a single disulfide bond under native conditions but is lost under reducing conditions leading to an apparent molecular weight of the receptor of $\sim 80$ $\mathrm{kDa}$ (26). In contrast, sustained receptor activation by $\mathrm{PTH}(1-34)$ resulting in continuous receptor internalization rendered the receptor inaccessible for extracellular proteases and thus protected the full-length receptor with a molecular weight of $\sim 90 \mathrm{kDa}$ (Fig 2C, left panel; c.f.

162 (26)). Similar to wild-type PTH1R, mutants where residues $64-71,80-87,88-95$ or 96-103 had been replaced by alanines migrated at $\sim 80 \mathrm{kDa}$ in reducing SDS-PAGE, indicating that protease cleavage was not prevented by the respective mutations. In contrast, PTH1R ${ }^{56-63 \mathrm{~A}}$ exclusively migrated at $\sim 90 \mathrm{kDa}$ similar to wild-type receptor where cleavage had been prevented by stimulation with $\mathrm{PTH}(1-34)$. For PTH1R ${ }^{72-79 \mathrm{~A}}$ two bands were detected which co-migrated with the cleaved and non-cleaved receptor species. Thus, mutating the region between $\mathrm{Leu}^{56}$ and $\mathrm{Met}^{63}$ to alanine fully inhibited proteolytic cleavage of the PTH1R ECD, indicating that the main cleavage site is located in this region. PTH1R ${ }^{72-79 \mathrm{~A}}$ exhibited incomplete inhibition of cleavage, suggesting another, less susceptible cleavage site or an incomplete masking of the cleavage site around residues 56-63.

To corroborate these findings, we determined the amino acid sequence of the N-terminus of the cleaved $80 \mathrm{kDa}$ fragment of PTH1R. PTH1R was purified from stably expressing Flp-In

$174 \mathrm{CHO}$ cells via a C-terminal Strep2 tag. $50 \mu \mathrm{g}$ of purified protein were blotted onto PVDF 175 membrane and stained with Coomassie blue. A band corresponding to the cleaved PTH1R 176 fragment was excised and analyzed by Edman degradation (Fig. 3A). Three different N177 termini were identified, located at positions $\mathrm{Ser}^{65}, \mathrm{Ser}^{73}$ and $\mathrm{Lys}^{80}$ in the ECD of PTH1R (Fig. 178 3B). Finally, the complete ECD of PTH1R (residues 23-177) was subjected to a 
computational cleavage site search using positional weight matrices (PWM) for 11 matrix metalloproteinases (MMPs) (30). This procedure revealed a total of 19 putative cleavage sites located between residues 30 to 173 . However, only cleavage site $\operatorname{Ser}^{61} \downarrow \operatorname{Ile}^{62}$ was common to all 11 MMPs and exhibited the highest PWM scores among all other predicted cleavage sites (Table 1). Taken together, these findings support the results of the alanine scan, suggesting that the primary cleavage occurs at $\operatorname{Ser}^{61} \downarrow \mathrm{Ile}^{62}$ of PTH1R.

185 To test whether ECD cleavage affected receptor function, we assessed activation of the two canonical signaling pathways of PTH1R $\mathrm{G}_{\mathrm{s}}$ (cyclic AMP, cAMP) and $\mathrm{G}_{\mathrm{q}}$ (inositol phosphates, IP) by wild-type PTH1R, by the fully cleavage-deficient mutant PTH1R ${ }^{56-63 \mathrm{~A}}$, and by the partially cleaved mutant PTH1R ${ }^{72-79 \mathrm{~A}}$. All measurements were performed in stably expressing $\mathrm{CHO}$ cells that had been matched for equal receptor expression levels. Compared to wild-type PTH1R, maximal PTH-induced generation of cAMP was reduced by $37 \%$ for PTH1R ${ }^{56-63 \mathrm{~A}}$, whereas no change was observed for PTH1R ${ }^{72-76 \mathrm{~A}}$ (Fig. 4A, Table 2). In contrast, PTHinduced generation of $\left[{ }^{3} \mathrm{H}\right] \mathrm{IP}$ was increased by $35 \%$ for PTH1 ${ }^{56-63 \mathrm{~A}}$, whereas no change was observed for PTH1R ${ }^{72-79 A}$ (Fig. 4B, Table 2). In summary, these findings suggest, that full cleavage of the ECD of PTH1R leads to decreased efficacy of PTH(1-34) in $\mathrm{G}_{\mathrm{q}}$ signaling and increased efficacy in $\mathrm{G}_{\mathrm{s}}$ signaling. PTH1R ${ }^{72-79 \mathrm{~A}}$ did not differ from wild-type PTH1R, which may be explained by the fact that the majority of PTH1 ${ }^{72-79 A}$ was still proteolytically processed (Fig. 3B). Thus, cleavage appears to directly modulate the signaling bias of PTH1R.

\section{Discussion}

200 Previously, we have reported that the ECD of PTH1R is subject to cleavage by metalloproteinases. PTH1R cleavage is a constitutive phenomenon and is inhibited by receptor activation (26). In the present study we aimed to characterize the role of proteolytic processing of the extracellular domain, and we provide evidence for the exact location of the cleavage site as well as for a modulation of signaling properties upon cleavage. N-terminal sequencing of the $80 \mathrm{kDa}$ receptor core (remaining after shedding the cleaved $\mathrm{N}$-terminal fragment by disulfide hydrolysis) revealed three nearby cleavage sites $\left(\mathrm{Glu}^{64} \downarrow \mathrm{Ser}^{65}\right.$, $\mathrm{Ala}^{72} \downarrow \operatorname{Ser}^{73}$ and $\left.\mathrm{Arg}^{79} \downarrow \mathrm{Lys}^{80}\right)$. However, computational analysis using cleavage patterns of 11 MMPs suggested a putative cleavage site at $\operatorname{Ser}^{61} \downarrow \mathrm{Ile}^{62}$ which was located 3 amino acids upstream of the first free N-terminus identified by microsequencing. A systematic alanine 
211 proteolysis, while mutation of residues 64-71 to alanine did not prevent proteolysis, further

212 supporting the proximal site at residue 61. Only a fraction of PTH1R ${ }^{72-79 A}$ remained intact

213 whereas the majority of receptor was found as the cleaved $80 \mathrm{kDa}$ form. This may suggest,

214 that the alanine mutations at residues 72-79 mask the cleavage site around residues 56-63 to

215 some extent or may hamper protease interaction resulting in incomplete protease cleavage.

216 Considering the results from computational and biochemical analyses, we propose that

$217 \operatorname{Ser}^{61} \downarrow \mathrm{Ile}^{62}$ is the most likely primary cleavage site. The free N-termini observed in Edman 218 degradation at $\mathrm{Ser}^{65}, \mathrm{Ser}^{73}$ and $\mathrm{Lys}^{80}$ may be the result of limited exopeptidase action

219 following endopeptidase cleavage. $\operatorname{Ser}^{61}$ is located within the first residues of a large loop 220 connecting the top layer formed by $\alpha 1$-helix with the first $\beta$-strand of the middle layer of the $221 \alpha-\beta-\beta-\alpha$ fold of PTH1R ECD. Notably, residues $61-104$ were not resolved in any structure of 222 PTH1R-ECD or full length PTH1R suggesting high flexibility in this region $(4,7,31)$. 223 Considering the orientation of the ECD in the full-length structures, Ser ${ }^{61}$ would be located at 224 the distal part of the receptor facing away from the membrane and, thus, may be well 225 accessible for extracellular proteases (Fig 1).

226 Processing by MMPs and other metalloproteinases has been described previously for a limited 227 number of other GPCRs, e.g. for $\beta_{1}$-adrenergic receptor (32), endothelin B receptor $(33,34)$, 228 thyrotropin receptor (35,36), protease-activated receptor 1 (PAR-1) (37,38), GPR124 (39) and 229 more recently for GPR37 (40,41). Apart from PAR-1 and the adhesion family receptor 230 GPR124, where protease cleavage unmasks the endogenous ligand resulting in receptor 231 activation, a functional consequence of protease cleavage has not been explicitly reported. To 232 our surprise, proteolytic cleavage of the PTH1R ECD directly affected receptor signaling. In 233 contrast to wild-type receptor, the cleavage-deficient mutant PTH1R ${ }^{56-63 \mathrm{~A}}$ exhibited reduced 234 cAMP and increased IP responses to PTH stimulation. Protease cleavage thus enhanced coupling efficacy of the receptor to the $G_{s}$ pathway, while reducing $G_{q}$-coupling at the same 236 time, resulting in a signaling bias. Biased signaling is defined as ligands giving different 237 degrees of activation in separate signaling pathways of the same receptor. Besides binding of 238 ligands to allosteric sites on the receptor that stabilize distinct active receptor conformations, 239 interaction of a receptor with intracellular adaptor proteins and subcellular receptor sequestration have been reported to affect signaling bias (42-44). For PTH1R, several ligands 241 and intracellular adaptors which direct signaling specificity to $G_{s}, G_{q}$ or $G$ protein242 independent pathways have been described (17,22,24,45-48). All of these PTH/PTHrP 243 derivatives carry modifications at the N-terminal part, which directly interacts with the 244 transmembrane domain of the receptor, suggesting that signaling specificity is mediated by 
direct conformational stabilization of the receptor core. Our findings now indicate that the ECD, which accommodates the C-terminal part of PTH and which is commonly believed to only serve as an "affinity trap" for the ligand, can also affect signaling specificity of the receptor.

There is growing evidence, that extracellular regions of GPCRs play important roles in finetuning receptor activity and signaling selectivity. Apart from PARs and adhesion receptors, where the buried ligand is proteolytically released from the receptor's N-terminus, extracellular loops play an important role in modulating the function of several class $\mathrm{A}$ and class B receptors (49). More importantly, calcium-mediated interaction of extracellular loop 1 and PTH has been shown to modulate PTH1R activity (50-52). Recent studies on glucagon receptor suggest that the ECD itself may act as an allosteric inhibitor by interaction of $\alpha 1$ helix of the ECD with extracellular loop 3 of the receptor core (53). Moreover, recent cryoEM structures of active-state class B GPCRs including PTH1R reveal a high degree of conformational flexibility of the ECD $(31,54,55)$, and it has been proposed that the dynamic motion of the ECD may contribute to biased agonism of class B GPCR ligands $(56,57)$. In 260 line with that, an antibody primarily binding to $\alpha 1$-helix of the ECD has been shown to modulate $\beta$-arrestin signaling of PTH1R (58) suggesting that perturbation of ECD orientation or conformation may alter receptor signaling. Proteolytic cleavage at $\mathrm{Ser}^{61}$ is expected to result in increased conformational flexibility of $\alpha 1$-helix of PTH1R ECD as the helix remains tethered to the receptor only through a disulfide bond between $\mathrm{Cys}^{48}$ and $\mathrm{Cys}^{117}$ (26). As a consequence, especially the N-terminal part of $\alpha 1$-helix may gain additional flexibility (Fig. 1). Notably, within this region residues 32-41 make important contacts to PTH including the flexible central region of the peptide (Fig. 5) $(4,7)$. This region was shown to be critical for initiating the two-step binding mechanism of PTH (59). Thus, it may well be conceivable that alterations in the flexibility and orientation of a1-helix of PTH1R ECD can allosterically affect receptor signaling. Whether these effects are mediated by an altered interaction of the

271 ECD with the transmembrane core, by a rearrangement of the ligand in the binding pocket, or 272 involve interaction of additional proteins such as RAMPs (receptor activity-modifying 273 proteins) with PTH1R $(60,61)$ needs to be studied.

274 In summary, we have mapped the cleavage site within the ECD of PTH1R and demonstrate 275 for the first time, to our knowledge, that protease cleavage of the ECD of a GPCR modulates $276 \mathrm{G}$ protein signaling specificity. 


\section{Conflict of Interest}

278 The authors declare that the research was conducted in the absence of any commercial or

279 financial relationships that could be construed as a potential conflict of interest.

\section{Author Contributions}

281 CK and MJL conceived the study; CK designed experiments; CK and LH performed 282 experiments; CK, LH and MJL analyzed data; CK wrote the manuscript, all authors provided 283 edits and comments.

\section{Funding}

285 These studies were supported by grants from the Deutsche Forschungsgemeinschaft (SFB487)

286 and the European Research Council (Advanced Grant TOPAS, No. 232944) to MJL.

\section{Acknowledgments}

288 We thank Michaela Hoffmann, Annette Hannawacker, Alexandra Bohl and Monika Frank for

289 technical assistance. Moreover, we thank Dr. Thomas Pohl (Wita GmbH, Berlin) for support 290 with N-terminal microsequencing. 


\section{References}

1. Jüppner H, Abou-Samra AB, Uneno S, Gu WX, Potts JT, Segre GV. The parathyroid hormone-like peptide associated with humoral hypercalcemia of malignancy and parathyroid hormone bind to the same receptor on the plasma membrane of ROS 17/2.8 cells. J Biol Chem (1988) 263:8557-8560.

2. Fredriksson R, Lagerström MC, Lundin L-G, Schiöth HB. The G-protein-coupled receptors in the human genome form five main families. Phylogenetic analysis, paralogon groups, and fingerprints. Mol Pharmacol (2003) 63:1256-1272. doi:10.1124/mol.63.6.1256

3. Lagerström MC, Schiöth HB. Structural diversity of G protein-coupled receptors and significance for drug discovery. Nat Rev Drug Discov (2008) 7:339-357. doi: $10.1038 / \mathrm{nrd} 2518$

4. Pioszak AA, Xu HE. Molecular recognition of parathyroid hormone by its G proteincoupled receptor. Proc Natl Acad Sci U S A (2008) 105:5034-5039. doi:10.1073/pnas.0801027105

5. Grauschopf U, Lilie H, Honold K, Wozny M, Reusch D, Esswein A, Schäfer W, Rücknagel KP, Rudolph R. The N-terminal fragment of human parathyroid hormone receptor 1 constitutes a hormone binding domain and reveals a distinct disulfide pattern. Biochemistry (2000) 39:8878-8887.

6. Karpf DB, Arnaud CD, Bambino T, Duffy D, King KL, Winer J, Nissenson RA. Structural properties of the renal parathyroid hormone receptor: hydrodynamic analysis and protease sensitivity. Endocrinology (1988) 123:2611-2620.

7. Ehrenmann J, Schöppe J, Klenk C, Rappas M, Kummer L, Doré AS, Plückthun A. High-resolution crystal structure of parathyroid hormone 1 receptor in complex with a peptide agonist. Nat Struct Mol Biol (2018) 25:1086-1092. doi:10.1038/s41594-0180151-4

8. Castro M, Nikolaev VO, Palm D, Lohse MJ, Vilardaga J-P. Turn-on switch in parathyroid hormone receptor by a two-step parathyroid hormone binding mechanism. Proc Natl Acad Sci U S A (2005) 102:16084-16089. doi:10.1073/pnas.0503942102

9. Gensure RC, Gardella TJ, Jüppner H. Parathyroid hormone and parathyroid hormonerelated peptide, and their receptors. Biochem Biophys Res Commun (2005) 328:666678. doi:10.1016/j.bbrc.2004.11.069

10. Friedman PA. PTH revisited. Kidney Int Suppl (2004)S13-S19. doi:10.1111/j.15231755.2004.09103.x

11. Jüppner H, Abou-Samra AB, Freeman M, Kong XF, Schipani E, Richards J, Kolakowski LF, Hock J, Potts JT, Kronenberg HM. A G protein-linked receptor for parathyroid hormone and parathyroid hormone-related peptide. Science (1991) 254:1024-1026.

12. Vilardaga J-P, Romero G, Friedman PA, Gardella TJ. Molecular basis of parathyroid hormone receptor signaling and trafficking: a family B GPCR paradigm. Cell Mol Life Sci (2011) 68:1-13. doi:10.1007/s00018-010-0465-9

13. Cole JA. Parathyroid hormone activates mitogen-activated protein kinase in opossum kidney cells. Endocrinology (1999) 140:5771-5779. doi:10.1210/endo.140.12.7173 
14. Mahon MJ, Bonacci TM, Divieti P, Smrcka AV. A docking site for G protein $\beta \gamma$ subunits on the parathyroid hormone 1 receptor supports signaling through multiple pathways. Mol Endocrinol (2006) 20:136-146. doi:10.1210/me.2005-0169

15. Singh ATK, Gilchrist A, Voyno-Yasenetskaya T, Radeff-Huang JM, Stern PH. G alpha12/G alpha13 subunits of heterotrimeric $\mathrm{G}$ proteins mediate parathyroid hormone activation of phospholipase D in UMR-106 osteoblastic cells. Endocrinology (2005) 146:2171-2175. doi:10.1210/en.2004-1283

16. Malecz N, Bambino T, Bencsik M, Nissenson RA. Identification of phosphorylation sites in the $G$ protein-coupled receptor for parathyroid hormone. Receptor phosphorylation is not required for agonist-induced internalization. Mol Endocrinol (1998) 12:1846-1856.

17. Gesty-Palmer D, Chen M, Reiter E, Ahn S, Nelson CD, Wang S, Eckhardt AE, Cowan CL, Spurney RF, Luttrell LM, et al. Distinct beta-arrestin- and G protein-dependent pathways for parathyroid hormone receptor-stimulated ERK1/2 activation. J Biol Chem (2006) 281:10856-10864. doi:10.1074/jbc.M513380200

18. Schwindinger WF, Fredericks J, Watkins L, Robinson H, Bathon JM, Pines M, Suva

19. Jilka RL. Molecular and cellular mechanisms of the anabolic effect of intermittent

20. Lee M, Partridge NC. Parathyroid hormone signaling in bone and kidney. Curr Opin Nephrol Hypertens (2009) 18:298-302. doi:10.1097/MNH.0b013e32832c2264

21. Whitfield JF, Morley P, Willick GE, Ross V, Barbier JR, Isaacs RJ, Ohannessian-Barry L. Stimulation of the growth of femoral trabecular bone in ovariectomized rats by the novel parathyroid hormone fragment, hPTH-(1-31)NH2 (Ostabolin). Calcif Tissue Int (1996) 58:81-87.

22. Yang D, Singh R, Divieti P, Guo J, Bouxsein ML, Bringhurst FR. Contributions of parathyroid hormone $(\mathrm{PTH}) / \mathrm{PTH}$-related peptide receptor signaling pathways to the anabolic effect of PTH on bone. Bone (2007) 40:1453-1461. doi:10.1016/j.bone.2007.02.001

23. Hilliker S, Wergedal JE, Gruber HE, Bettica P, Baylink DJ. Truncation of the amino terminus of PTH alters its anabolic activity on bone in vivo. Bone (1996) 19:469-477.

24. Gesty-Palmer D, Flannery P, Yuan L, Corsino L, Spurney R, Lefkowitz RJ, Luttrell LM. A beta-arrestin-biased agonist of the parathyroid hormone receptor (PTH1R) promotes bone formation independent of G protein activation. Sci Transl Med (2009) 1:1ra1. doi:10.1126/scitranslmed.3000071

25. Potts JT. Parathyroid hormone: past and present. J Endocrinol (2005) 187:311-325. doi:10.1677/joe.1.06057

26. Klenk C, Schulz S, Calebiro D, Lohse MJ. Agonist-regulated cleavage of the extracellular domain of parathyroid hormone receptor type 1. J Biol Chem (2010) 285:8665-8674. doi:10.1074/jbc.M109.058685

27. Lupp A, Klenk C, Röcken C, Evert M, Mawrin C, Schulz S. Immunohistochemical identification of the PTHR1 parathyroid hormone receptor in normal and neoplastic human tissues. Eur J Endocrinol (2010) 162:979-986. doi:10.1530/EJE-09-0821 
28. Klenk C, Vetter T, Zürn A, Vilardaga J-P, Friedman PA, Wang B, Lohse MJ. Formation of a ternary complex among NHERF1, beta-arrestin, and parathyroid hormone receptor. $J$ Biol Chem (2010) 285:30355-30362. doi:10.1074/jbc.M110.114900

29. Emami-Nemini A, Gohla A, Urlaub H, Lohse MJ, Klenk C. The guanine nucleotide exchange factor Vav2 is a negative regulator of parathyroid hormone receptor/Gq signaling. Mol Pharmacol (2012) 82:217-225. doi:10.1124/mol.112.078824

30. Kumar S, Ratnikov BI, Kazanov MD, Smith JW, Cieplak P. CleavPredict: A Platform for Reasoning about Matrix Metalloproteinases Proteolytic Events. PLoS ONE (2015) 10:e0127877. doi:10.1371/journal.pone.0127877

31. Zhao L-H, Ma S, Sutkeviciute I, Shen D-D, Zhou XE, de Waal PW, Li C-Y, Kang Y, Clark LJ, Jean-Alphonse FG, et al. Structure and dynamics of the active human parathyroid hormone receptor-1. Science (2019) 364:148-153. doi:10.1126/science.aav7942

393

394

32. Hakalahti AE, Vierimaa MM, Lilja MK, Kumpula E-P, Tuusa JT, Petäjä-Repo UE. Human beta1-Adrenergic Receptor Is Subject to Constitutive and Regulated N-terminal Cleavage. J Biol Chem (2010) 285:28850-28861. doi:10.1074/jbc.M110.149989

33. Kozuka M, Ito T, Hirose S, Lodhi KM, Hagiwara H. Purification and characterization of bovine lung endothelin receptor. J Biol Chem (1991) 266:16892-16896.

34. Grantcharova E, Furkert J, Reusch HP, Krell H-W, Papsdorf G, Beyermann M, Schulein R, Rosenthal W, Oksche A. The extracellular N terminus of the endothelin B (ETB) receptor is cleaved by a metalloprotease in an agonist-dependent process. $J$ Biol Chem (2002) 277:43933-43941. doi:10.1074/jbc.M208407200

35. Couet J, Sar S, Jolivet A, Hai MT, Milgrom E, Misrahi M. Shedding of human thyrotropin receptor ectodomain. Involvement of a matrix metalloprotease. J Biol Chem (1996) 271:4545-4552.

36. Kaczur V, Puskas LG, Nagy ZU, Miled N, Rebai A, Juhasz F, Kupihar Z, Zvara A, Hackler L, Farid NR. Cleavage of the human thyrotropin receptor by ADAM10 is regulated by thyrotropin. J Mol Recognit (2007) 20:392-404. doi:10.1002/jmr.851

37. Boire A, Covic L, Agarwal A, Jacques S, Sherifi S, Kuliopulos A. PAR1 is a matrix metalloprotease-1 receptor that promotes invasion and tumorigenesis of breast cancer cells. Cell (2005) 120:303-313. doi:10.1016/j.cell.2004.12.018

38. Ludeman MJ, Zheng YW, Ishii K, Coughlin SR. Regulated shedding of PAR1 Nterminal exodomain from endothelial cells. J Biol Chem (2004) 279:18592-18599. doi:10.1074/jbc.M310836200

39. Vallon M, Essler M. Proteolytically processed soluble tumor endothelial marker (TEM) 5 mediates endothelial cell survival during angiogenesis by linking integrin alpha(v)beta3 to glycosaminoglycans. J Biol Chem (2006) 281:34179-34188. doi:10.1074/jbc.M605291200

40. Mattila SO, Tuhkanen HE, Lackman JJ, Konzack A, Morató X, Argerich J, Saftig P, Ciruela F, Petäjä-Repo UE. GPR37 is processed in the N-terminal ectodomain by ADAM10 and furin. FASEB J (2021) 35:e21654. doi:10.1096/fj.202002385RR

41. Mattila SO, Tuusa JT, Petäjä-Repo UE. The Parkinson's-disease-associated receptor GPR37 undergoes metalloproteinase-mediated N-terminal cleavage and ectodomain shedding. J Cell Sci (2016) 129:1366-1377. doi:10.1242/jcs.176115 
42. Luttrell LM, Maudsley S, Bohn LM. Fulfilling the Promise of "Biased" G ProteinCoupled Receptor Agonism. Mol Pharmacol (2015) 88:579-588. doi:10.1124/mol.115.099630

43. Kenakin TP. New concepts in pharmacological efficacy at 7TM receptors: IUPHAR review 2. Br J Pharmacol (2013) 168:554-575. doi:10.1111/j.1476-5381.2012.02223.x

44. Onaran HO, Rajagopal S, Costa T. What is biased efficacy? Defining the relationship between intrinsic efficacy and free energy coupling. Trends Pharmacol Sci (2014) 35:639-647. doi:10.1016/j.tips.2014.09.010

47. Jouishomme H, Whitfield JF, Chakravarthy B, Durkin JP, Gagnon L, Isaacs RJ,

45. Bisello A, Chorev M, Rosenblatt M, Monticelli L, Mierke DF, Ferrari SL. Selective ligand-induced stabilization of active and desensitized parathyroid hormone type 1 receptor conformations. $J$ Biol Chem (2002) 277:38524-38530. doi:10.1074/jbc.M202544200

46. Takasu H, Gardella TJ, Luck MD, Potts JT, Bringhurst FR. Amino-terminal modifications of human parathyroid hormone (PTH) selectively alter phospholipase $\mathrm{C}$ signaling via the type 1 PTH receptor: implications for design of signal-specific PTH ligands. Biochemistry (1999) 38:13453-13460.

Maclean S, Neugebauer W, Willick G, Rixon RH. The protein kinase-C activation domain of the parathyroid hormone. Endocrinology (1992) 130:53-60. doi:10.1210/endo.130.1.1727720

48. Azarani A, Goltzman D, Orlowski J. Structurally diverse N-terminal peptides of parathyroid hormone (PTH) and PTH-related peptide (PTHRP) inhibit the $\mathrm{Na}+\mathrm{H}+$ exchanger NHE3 isoform by binding to the PTH/PTHRP receptor type I and activating distinct signaling pathways. J Biol Chem (1996) 271:14931-14936.

49. Wheatley M, Wootten D, Conner MT, Simms J, Kendrick R, Logan RT, Poyner DR, Barwell J. Lifting the lid on GPCRs: the role of extracellular loops. Br J Pharmacol (2012) 165:1688-1703. doi:10.1111/j.1476-5381.2011.01629.x

50. White AD, Fang F, Jean-Alphonse FG, Clark LJ, An H-J, Liu H, Zhao Y, Reynolds SL, Lee S, Xiao K, et al. Ca2+ allostery in PTH-receptor signaling. Proc Natl Acad Sci U S A (2019) 116:3294-3299. doi:10.1073/pnas.1814670116

51. Li M, Li M, Guo J. Molecular Mechanism of Ca2+ in the Allosteric Regulation of Human Parathyroid Hormone Receptor-1. J Chem Inf Model (2021) doi:10.1021/acs.jcim.1c00471

52. Mitra N, Liu Y, Liu J, Serebryany E, Mooney V, Devree BT, Sunahara RK, Yan ECY. Calcium-dependent ligand binding and G-protein signaling of family B GPCR parathyroid hormone 1 receptor purified in nanodiscs. ACS Chem Biol (2013) 8:617625. doi:10.1021/cb300466n

53. Koth CM, Murray JM, Mukund S, Madjidi A, Minn A, Clarke HJ, Wong T, Chiang V, Luis E, Estevez A, et al. Molecular basis for negative regulation of the glucagon receptor. Proc Natl Acad Sci $U$ S A (2012) 109:14393-14398. doi:10.1073/pnas.1206734109

54. Liang Y-L, Khoshouei M, Deganutti G, Glukhova A, Koole C, Peat TS, Radjainia M, Plitzko JM, Baumeister W, Miller LJ, et al. Cryo-EM structure of the active, Gs-protein complexed, human CGRP receptor. Nature (2018) 561:492-497. doi:10.1038/s41586018-0535-y 
55. Dal Maso E, Glukhova A, Zhu Y, García-Nafría J, Tate CG, Atanasio S, Reynolds CA, Ramírez-Aportela E, Carazo J-M, Hick CA, et al. The Molecular Control of Calcitonin Receptor Signaling. ACS Pharmacology \& Translational Science (2019) 2:31-51. doi:10.1021/acsptsci.8b00056

56. Liang Y-L, Khoshouei M, Glukhova A, Furness SGB, Zhao P, Clydesdale L, Koole C, Truong TT, Thal DM, Lei S, et al. Phase-plate cryo-EM structure of a biased agonistbound human GLP-1 receptor-Gs complex. Nature (2018) 68:954. doi: $10.1002 /$ jcc. 20084

57. Lei S, Clydesdale L, Dai A, Cai X, Feng Y, Yang D, Liang Y-L, Koole C, Zhao P, Coudrat T, et al. Two distinct domains of the glucagon-like peptide-1 receptor control peptide-mediated biased agonism. J Biol Chem (2018) 293:9370-9387. doi:10.1074/jbc.RA118.003278

58. Sarkar K, Joedicke L, Westwood M, Burnley R, Wright M, McMillan D, Byrne B. Modulation of PTH1R signaling by an ECD binding antibody results in inhibition of $\beta$ arrestin 2 coupling. Sci Rep (2019) 9:14432. doi:10.1038/s41598-019-51016-z

59. Clark LJ, Clark LJ, Krieger J, Krieger J, White AD, White AD, Bondarenko V, Bondarenko V, Lei S, Lei S, et al. Allosteric interactions in the parathyroid hormone GPCR-arrestin complex formation. Nat Chem Biol (2020) 42:946. doi:10.1007/s13361-011-0261-2

60. Christopoulos A, Christopoulos G, Morfis M, Udawela M, Laburthe M, Couvineau A, Kuwasako K, Tilakaratne N, Sexton PM. Novel receptor partners and function of receptor activity-modifying proteins. J Biol Chem (2003) 278:3293-3297. doi:10.1074/jbc.C200629200

61. Nemec K, Schihada H, Kleinau G, Zabel U, Grushevskyi EO, Scheerer P, Lohse MJ, Maiellaro I. Functional modulation of PTH1R activation and signalling by RAMP2. bioRxiv (2021)2021.12.08.471790. doi:10.1101/2021.12.08.471790

62. Schechter I, Berger A. On the size of the active site in proteases. I. Papain. Biochem Biophys Res Commun (1967) 27:157-162. doi:10.1016/j.bbrc.2012.08.015 


\section{Tables}

501 Table 1 - Computational cleavage site prediction of PTH1R ECD. The sequence of the 502 mature PTH1R ECD (amino acids 23-177) was analyzed for MMP cleavage sites with 503 CleavPredict (30) using position weight matrices for 11 MMPs (MMP-2, MMP-3, MMP-8, 504 MMP-9, MMP-13, MMP-14, MMP-15, MMP-16, MMP-17, MMP-24, MMP-25). For each 505 cleavage site, the residue number of P1, the sequence corresponding to P5-P5' (numbering 506 according to Schechter and Berger (62)) and the position weight matrix score (PWM score) 507 for each MMP subtype are given.

\begin{tabular}{|c|c|c|c|c|c|c|c|c|c|c|c|c|}
\hline \multirow{2}{*}{$\begin{array}{c}\text { P1 } \\
\text { position }\end{array}$} & \multirow{2}{*}{$\begin{array}{l}\text { residues } \\
\text { (P5-P5') }\end{array}$} & \multicolumn{11}{|c|}{ MMP } \\
\hline & & 2 & 3 & 8 & 9 & 10 & 14 & 15 & 16 & 17 & 24 & 25 \\
\hline 30 & VDADD $\downarrow$ VMTKE & & & & & & & & & & & 1.32 \\
\hline 37 & TKEEQ $\downarrow$ IFLLH & & & & & & & & & & & 0.19 \\
\hline 40 & EQIFL $\downarrow$ LHRAQ & & 3.46 & & & 2.19 & & & & 3.43 & & 1.50 \\
\hline 46 & HRAQA $\downarrow Q C E K R$ & & & & & & & & & 2.37 & & 1.71 \\
\hline 51 & QCEKR $\downarrow$ LKEVL & & & & & & & & & & & \\
\hline 61 & QRPAS $\downarrow$ IMESD & 6.75 & 8.76 & 6.13 & 5.72 & 8.26 & 7.60 & 5.37 & 7.00 & 3.42 & 7.88 & 5.82 \\
\hline 80 & GKPRK $\downarrow D K A S G$ & 1.36 & & & & & & & & & & \\
\hline 86 & KASGK $\downarrow L Y P E S$ & & & 1.63 & & & & 1.31 & & 2.44 & & 4.71 \\
\hline 100 & EAPTG $\downarrow S R Y R G$ & & & & 2.52 & & & & & & & \\
\hline 102 & PTGSR $\downarrow$ YRGRP & & & 1.90 & & & & & & & & \\
\hline 114 & PEWDH $\downarrow I L C W P$ & & & & & & & 2.62 & & & & \\
\hline 125 & GAPGE $\downarrow$ VVAVP & 3.56 & 3.14 & 2.03 & & & & & & & & 0.21 \\
\hline 134 & PCPDY $\downarrow I Y D F N$ & & & 2.48 & & 1.64 & & 5.02 & & & & 4.48 \\
\hline 137 & DYIYD $\downarrow F N H K G$ & & & 2.06 & & & & & & & & \\
\hline 144 & HKGHA $\downarrow$ YRRCD & & & 2.67 & & & & & & & 0.81 & \\
\hline 155 & NGSWE $\downarrow L V P G H$ & & & 5.18 & & & & & & 2.47 & & 4.00 \\
\hline 160 & LVPGH $\downarrow N R T W A$ & 2.05 & & & & & 1.74 & 2.03 & 1.35 & & & \\
\hline 166 & RTWAN $\downarrow$ YSECV & & & & & & 1.97 & & 2.16 & & & \\
\hline 173 & ECVKF $\downarrow$ LTNET & & & 3.15 & 6.44 & & 1.30 & & 2.98 & 3.50 & & 4.39 \\
\hline
\end{tabular}


509 Table 2 - Effects of ECD cleavage on cAMP generation and IP accumulation. PTH-

510 induced $\mathrm{E}_{\max }$ values for cAMP and IP generation of PTH1R ${ }^{56-63 \mathrm{~A}}$ or PTH1R ${ }^{72-79 A}$. were

511 compared against that of PTH1R using unpaired $t$ tests. Data summarize results of 3-5

512 independent experiments.

\begin{tabular}{|c|c|c|c|c|c|c|}
\hline & \multicolumn{3}{|c|}{ Difference vs. PTH1R, cAMP (\%) } & \multicolumn{3}{|c|}{ Difference vs. PTH1R, $\left[{ }^{3} \mathrm{H}\right] \mathrm{IP}(\%)$} \\
\hline & $\begin{array}{c}\text { Mean } \pm \\
\text { SEM }\end{array}$ & 95\% C.I. & $p$ & $\begin{array}{l}\text { Mean } \pm \\
\text { SEM }\end{array}$ & 95\% C.I. & $p$ \\
\hline PTH1R ${ }^{56-63 \mathrm{~A}}$ & $-37.3 \pm 5.9$ & -52.7 to -21.9 & 0.0015 & $35.3 \pm 10.7$ & 10.6 to 60.1 & 0.011 \\
\hline PTH1R ${ }^{72-79 A}$ & $-1.9 \pm 1.3$ & -5.3 to 1.5 & 0.21 & $-5.6 \pm 19.4$ & -48.8 to 37.6 & 0.78 \\
\hline
\end{tabular}

C.I., confidence interval 


\section{Figures}

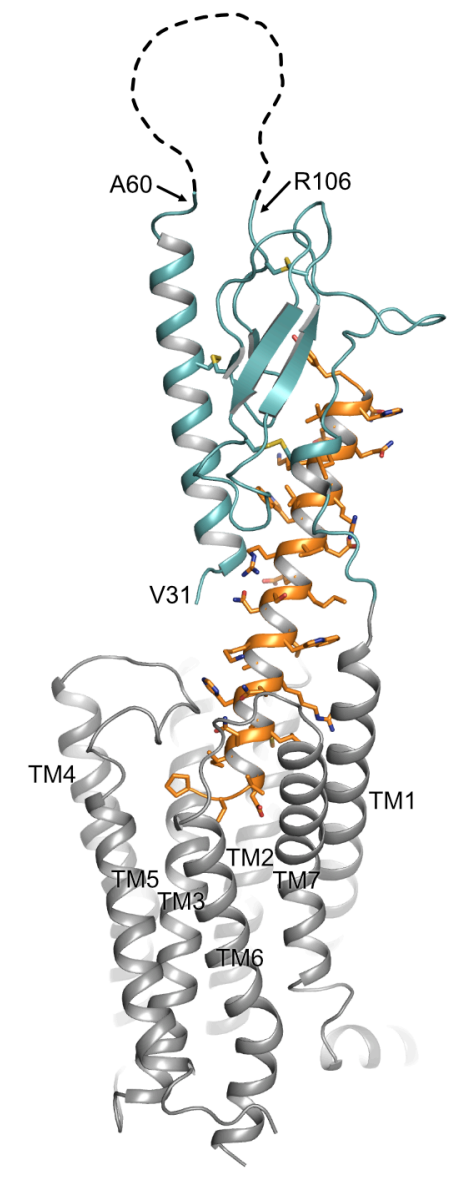

516 Figure 1 - Topology of PTH1R. Structure of the human PTH1R (transmembrane domain,

517 grey; ECD, teal) in complex with a PTH analog (orange) (PDB ID: 6FJ3). Unstructured

518 residues 61-105 of ECD loop 1 are depicted as a dashed line. The receptor N-terminal residue $519\left(\mathrm{~V}^{31}\right.$, as resolved in the crystal structure), residues embracing ECD loop1, and transmembrane 520 helices (TM1-7) are indicated. 


\section{A}

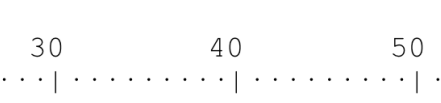

50

60

E2

YALVDADDVMTKEEQIFLLHRAQAQCEKRLKEVLQRPASIMESDKGWTSASTSGKPRKDKASGKLYPESEEDKEAPTGSRYRGRPC

$56-63 \mathrm{~A}$

$64-71 \mathrm{~A}$

$72-79 A$

80-87A

88-95A 96-103A

\section{B}
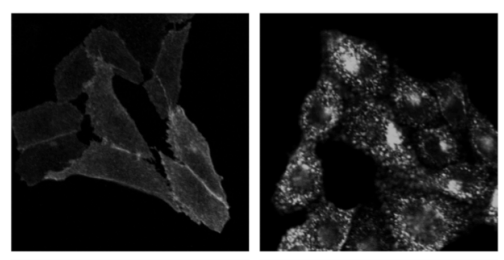

WT
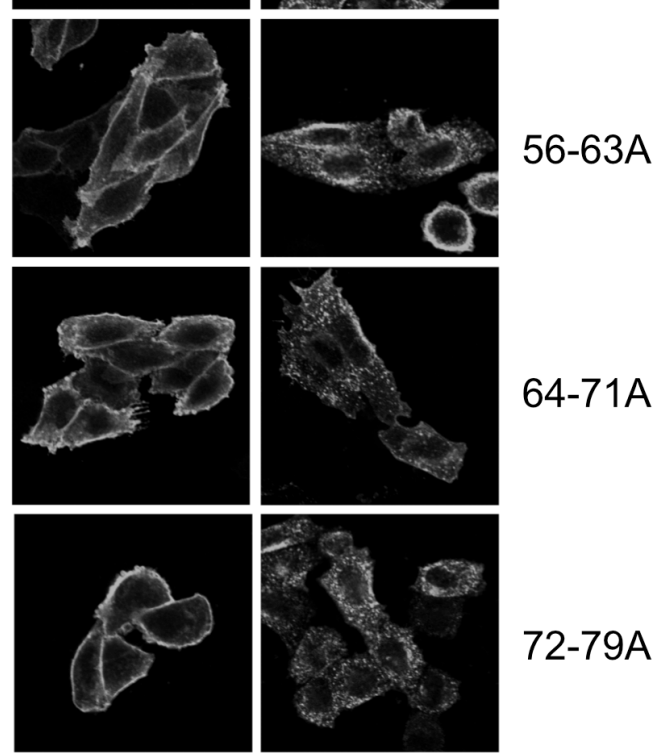

64-71A

n.s.

$\mathrm{PTH}(1-34)$

\section{2-79A}
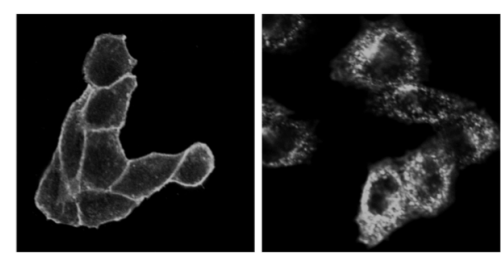

80-87A
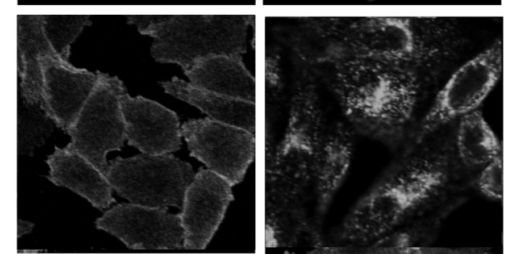

88-95A
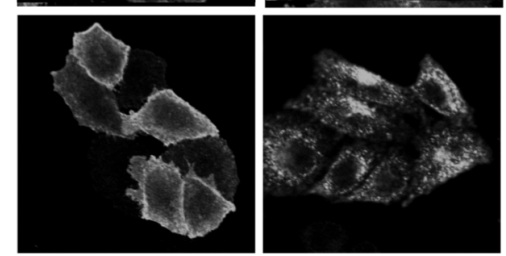

96-103A

n.s.

PTH(1-34)

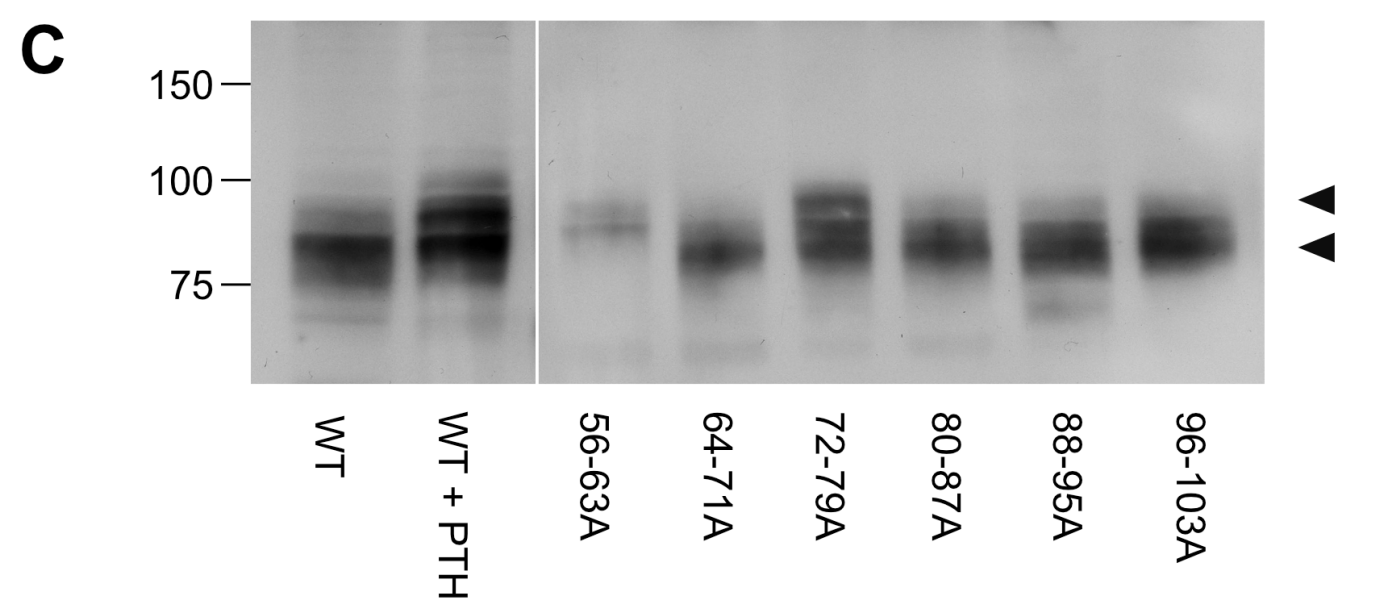


522 Figure 2 - Mapping of the protease cleavage site of PTH1R ECD by alanine scan. (A)

523 Amino acid sequence of the extracellular domain of the human PTH1R. Stretches of 8 amino

524 acids that were replaced by alanine residues are indicated by horizontal bars. Exon E2 is

525 marked above the sequence. (B) CHO cells stably expressing PTHR variants were treated

526 with $100 \mathrm{nM}$ PTH(1-34) for $30 \mathrm{~min}$ or left untreated. Subsequently, cells were fixed,

527 permeabilized, and stained with rabbit anti-PTH1R antibody followed by Cy2-labeled anti-

528 rabbit antibody. PTHR was visualized by confocal microscopy. (C) CHO cells stably

529 expressing PTHR variants were lysed, and PTH1R was monitored by reducing SDS-PAGE

530 and Western blotting. Cells were treated with $100 \mathrm{nM} \mathrm{PTH}(1-34)$ for $12 \mathrm{~h}$ prior to cell lysis

531 where indicated. Arrowheads depict the cleaved (MW $\sim 80 \mathrm{kDa}$ ) and the uncleaved (MW $532 \sim 90 \mathrm{kDa})$ PTH1R band. 
A

B
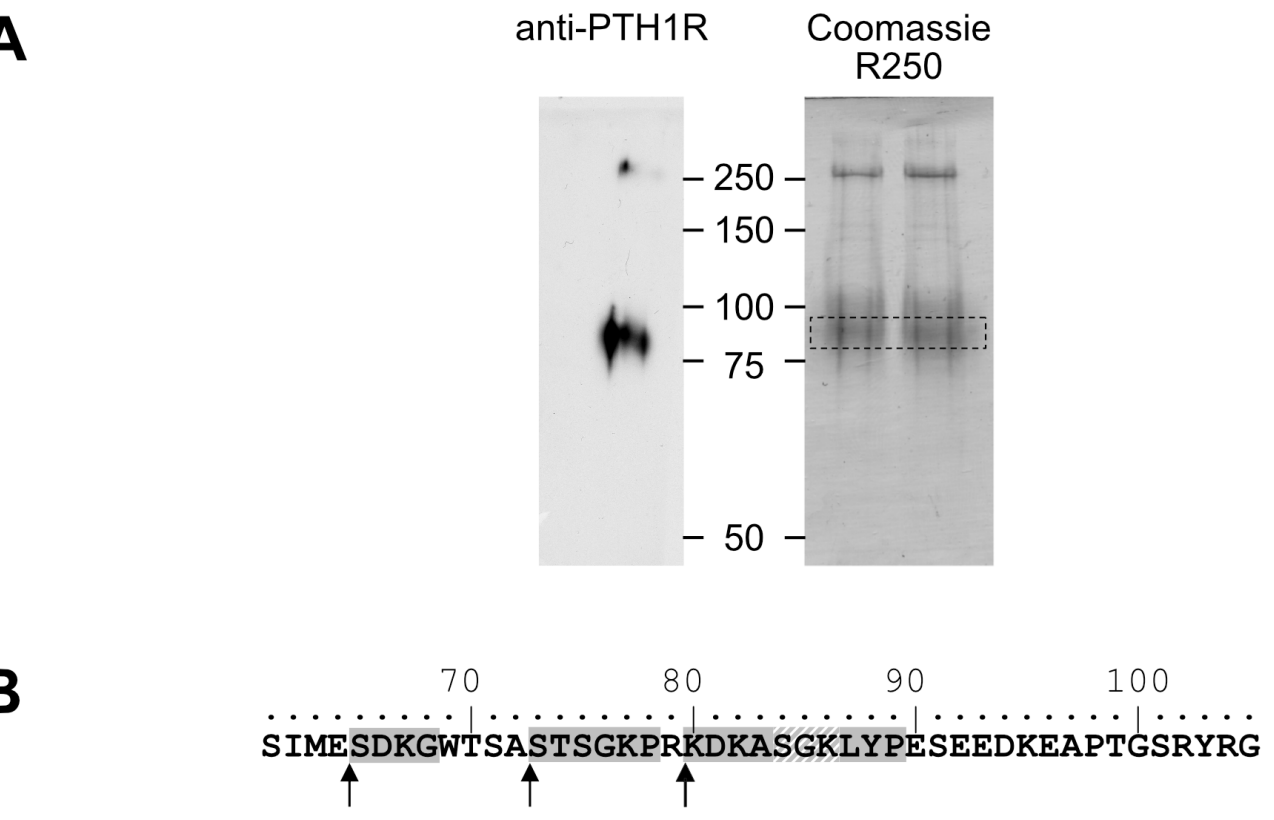

534 Figure 3 - Mapping of the protease cleavage site of PTH1R ECD by N-terminal

535 sequencing. (A) Human PTH1R with C-terminal Strep2-tag was purified from stably

536 expressing CHO cells by two-step affinity purification. A fraction of the purified receptor was

537 subjected to Western blot and probed with anti-PTH1R antibodies (left panel). The remaining

538 purified receptor protein $(\sim 50 \mu \mathrm{g})$ was transferred on PVDF membranes and stained with

539 Coomassie blue R250. The band corresponding to PTH1R was cut out and subjected to

540 microsequencing (right panel, dashed box). (B) Sequence of exon E2 (amino acids 61-105).

541 Sequences obtained from microsequencing are shaded gray. The position of the N-terminal

542 amino acid is marked by an arrow. Residues 84-86 (gray diagonal stripes) were not resolved

543 in the Edman degradation. 
A

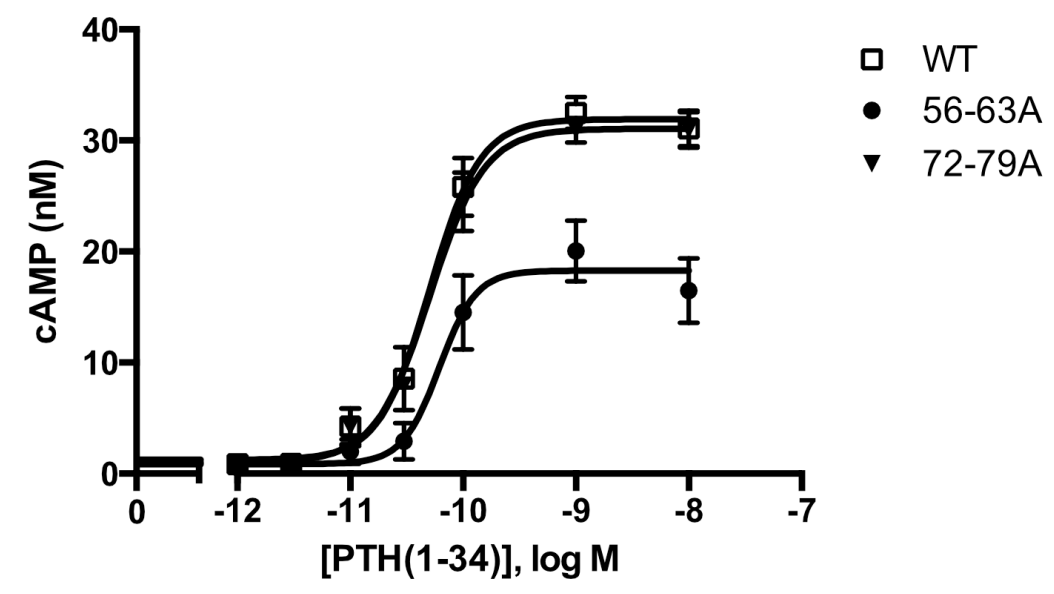

B

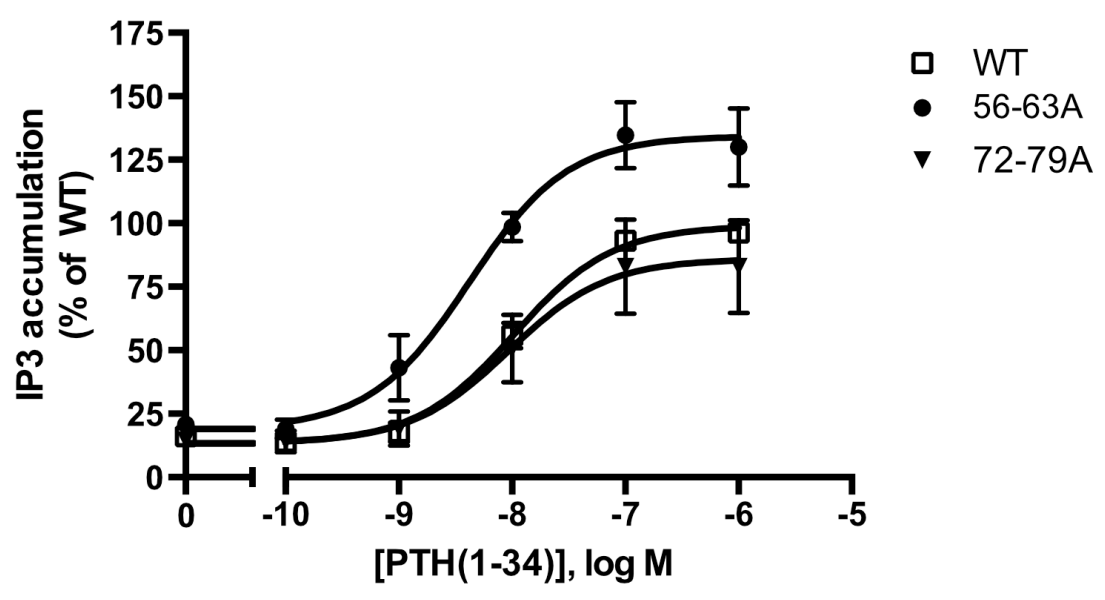

546 Figure 4 - Protease cleavage changes the signaling specificity of PTH1R from $\mathbf{G}_{\mathbf{q}}$ and $\mathbf{G}_{\mathbf{s}}$.

547 (A) Flp-In CHO cells stably expressing PTH1R, PTH1R ${ }^{56-63 \mathrm{~A}}$ or PTH1R ${ }^{72-79 \mathrm{~A}}$ were stimulated

548 for 20 min with PTH(1-34) at the indicated concentrations, and cAMP levels were quantified

549 with a radioimmunoassay. The means \pm S.E.M. of five independent experiments are shown.

550 (B) Flp-In CHO cells stably expressing PTH1R, PTH1R ${ }^{56-63 \mathrm{~A}}$ or PTH1R ${ }^{72-79 \mathrm{~A}}$ were incubated 551 with $\left[m y o-2-{ }^{3} \mathrm{H}(\mathrm{N})\right]$ inositol and $0.2 \%$ fetal calf serum for $16 \mathrm{~h}$. Cells were stimulated for 55260 min with the indicated concentrations of PTH, and $\left[{ }^{3} \mathrm{H}\right] \mathrm{IP} \mathrm{P}_{3}$ levels were quantified in a 553 scintillation counter after chromatographic separation. Data represent the means \pm S.E.M. of 554 five individual experiments. 


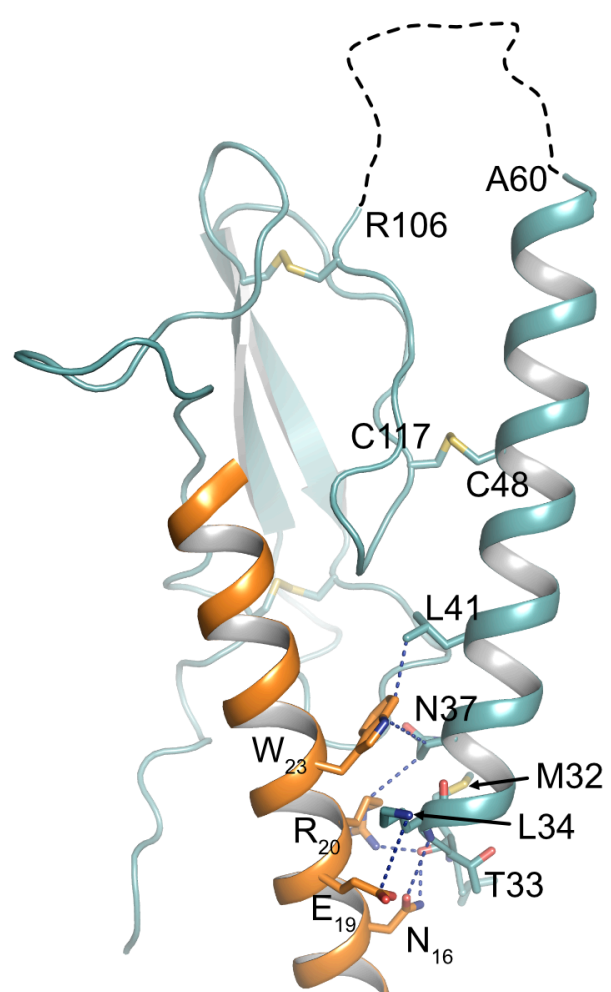

557 Figure 5 - Interface between PTH and a1-helix of PTH1R ECD. Crystal structure of the 558 PTH1R ECD (teal) in complex with PTH (orange) (PDB ID: 6FJ3). Residues forming the 559 interface are shown as stick, and contacts are indicated as blue dashed lines. The unstructured 560 loop 1 of the ECD is shown as black dashed line. 